\title{
Cell wall associated immunity in plants
}

\author{
Jiangxue Wan ${ }^{1+}$, Min He ${ }^{1+}$, Qingqing Hou' ${ }^{1}$ Lijuan Zou ${ }^{1,2}$, Yihua Yang ${ }^{1}$, Yan Wei ${ }^{1}$ and Xuewei Chen ${ }^{1 *}$
}

\begin{abstract}
The plant cell wall is the first physical and defensive barrier against pathogens. The plant cell wall usually undergoes dynamic remodeling as an immune response to prevent infection by pathogens. In this review, we summarize advances on relationship between cell wall and immunity in plants. In particular, we outline current progresses regarding the regulation of the cell wall components, including cellulose, hemicellulose, pectin and lignin, on plant disease resistance. We also discuss the impacts of cell wall-derived cellodextrin, oligogalacturonic acid and xyloglucan/xylan oligosaccharides as potent elicitors or signal molecules to trigger plant immune response. We further propose future studies on dissecting the molecular regulation of cell wall on plant immunity, which have potentials in practical application of crop breeding aiming at improvement of plant disease resistance.
\end{abstract}

Keywords: Cell wall, Oligosaccharides, Elicitor, Plant immunity, Disease resistance

\section{Introduction}

Plants are consistently confronted with biotic stresses imposed by insects or pathogens during their growth within the natural environments (Panstruga et al. 2009). These stressful restrictions force plants to develop cellautonomous monitoring systems to cope with the harsh conditions for balancing the stress response and their growth (Hofte and Voxeur 2017; Engelsdorf and Hamann 2014). Plants have therefore evolved complicated and effective mechanisms with the long-term adaptation to resist stresses (Glazebrook 2005). The plant cell wall acts as the first physical barrier to defend against invasion of pathogens, and it is also involved in sensing external stresses and transferring the corresponding signal to stimulate defense responses (Cosgrove 2005). The cell wall is often regarded as a passive barrier upon pathogens attack, but recently, growing evidence has shown that it more likely functions initiatively.

The structure and component of cell wall vary with plant species, developmental stage and response to stress

\footnotetext{
*Correspondence: xwchen88@163.com

†Jiangxue Wan and Min He contributed equally to this work.

'State Key Laboratory of Crop Gene Exploration and Utilization in Southwest China, Sichuan Agricultural University at Wenjiang, Chengdu 611130,

Sichuan, China

Full list of author information is available at the end of the article
}

(Scheller and Ulvskov 2010). As an important monitoring system, the plant cell wall undergoes dynamic remodeling in adaption to external stresses including pathogenic infection by microbes (Zhao and Dixon 2014). Reinforcement of cell wall has been confirmed as a typical physiological consequence of activated immune response in plants (Luna et al. 2010; Underwood 2012). Emerging evidence indicates that the cell wall integrity (CWI) maintenance is important for activating and monitoring the defense responses (Vaahtera et al. 2019). In this regard, alternations of the plant cell wall are considered to interconnect with the two-layered innate immune system composed of the pathogen-associated molecular pattern-triggered immunity (PTI) and effector-triggered immunity (ETI). PTI is the first layer of immunity which is activated when the host pattern recognition receptor (PRR) senses the pathogenassociated molecular pattern (PAMP). To evade PTI, microbial pathogens secrete effectors to dampen plant defense response. Plants have accordingly evolved resistance proteins, typically those with nucleotide binding site-leucine-rich repeat (NLR) domains, to recognize pathogens' effectors to initiate the second layer of defense called ETI (Jones and Dangl 2006). Among increasing knowledge on regulatory mechanism of PTI and ETI, emerging evidence shows that the component and modification of cell wall are associated with plant 
immunity (Nicaise et al. 2009; Wolf et al. 2012). Here, we review current progresses concerning the modulation of cell wall on plant immunity.

\section{Cell wall synthesis and structure}

The plant cell wall is a complex network composed of various polysaccharides. The presence of cellulose, hemicellulose and pectin is a common feature for all plants' cell wall (Cosgrove 2005), which is generally divided into two types. Cellulose microfibril is similarly present in type I and type II cell wall. The main difference in component between the two types of cell wall is the non-cellulosic polysaccharides. Xyloglucans is the main non-cellulosic polysaccharide in type I cell wall, while arabinoxylan and $\beta-(1 \rightarrow 3,1 \rightarrow 4)$ mixed-linkage glucan (MLG) are predominant in type II cell wall (Wolf et al. 2012). The type I cell wall is mainly present in dicots including Arabidopsis thaliana, while the type II exits in monocots like poaceae (Carpita and Gibeaut 1993). Cellulose accounts for about one-third of the cell wall biomass (Fig. 1), thus constituting a key component of the plant cell wall and being regarded as the most abundant biological polymer on earth (Zhong et al. 2019). The cellulose filament is formed by 36 unbranched $\beta$-1,4-glucan chains through hydrogen bonding and intermolecular forces (Taylor 2008). The compacted cellulose filaments serve as the basic skeleton of cell wall to allow for mechanical properties in plant (Somerville 2006).

Hemicellulose is another major component of plant cell wall (Fig. 1). It is made up of diverse polysaccharides including xylan, xyloglucan, mannan, glucomannan and MLG. Hemicellulose polysaccharides confer strength to the cell wall by interacting with cellulose and lignin (Scheller and Ulvskov 2010). Arabinoxylan and MLG make up most of the hemicellulose in poaceae (Carpita and Gibeaut 1993). Among the different polysaccharides in dicots hemicellulose, xyloglucan is the main component in primary cell wall. The basic structure of xyloglucan is composed of $\beta$-(1 $\rightarrow 4)$-glucan backbone which contains xylose as residues at $0-6$ position of glucose. The xylose within xyloglucan can further be decorated with galatosyl and galatosyl-fucosyl residues. Those decorations usually vary between plant species (Park and Cosgrove 2015; Schultink et al. 2014).

Pectin is formed by various polysaccharides and its main chain is $\alpha$-1,4-galacturonic acid (Fig. 1). The content of pectin varies between different plants. For example, pectin accounts for approximately $35 \%$ of primary cell wall in dicots and non-graminaceous monocots, whereas accounts for only $2-10 \%$ of gramineae such as rice (O'Neill and Albersheim 1990; Ridley et al. 2001). There are mainly four different types of pectin polysaccharides, viz homogalacturonan (HG), rhamnogalacturonan-I (RG-I), rhamnogalacturonan-II (RG-II) and xylogalacturonan
(XGA). Homogalacturonan, as a homopolymer of $\alpha-1$, 4galacturonic acid, is the most abundant pectin by occupying about 60\% (Ridley et al. 2001; Caffall and Mohnen 2009). Compared to the homogeneity of homogalacturonan, RG-II is composed of $\alpha-1,4$-galacturonic acid containing complicated substitutions, while RG-I is the only pectin polysaccharides with mixed backbone of disaccharide ( $\alpha-1,4-\mathrm{D}-\mathrm{GlaA}-\alpha-1,2-\mathrm{L}-\mathrm{Rh})$ and with substitutions on rhamnose (Ridley et al. 2001; Harholt et al. 2010). RG-II and RG-I occupies approximately $10 \%$ and $20-35 \%$ of pectin respectively (Arana et al. 2009). Xylogalacturonan has xylose substituents at the $O-3$ position of the main chain of galacturonic acid, and it constitutes minor proportion of pectin (Ridley et al. 2001).

Compared to the cellulose-based plant cell wall, fungal cell wall mainly consists of an outer layer of glycoproteins and an inner skeletal layer of gluca and chitin (Arana et al. 2009). Proteins occupy about $35-40 \%$ of total fungal cell wall in content (Fontaine et al. 2000). Most of the fungal cell wall proteins are glycoproteins modified with $\mathrm{N}$ - and $\mathrm{O}$-linked oligosaccharides. The oligosaccharides form different structures in fungi, but their main components are mannan and galactomannan (Jin 2012). As the major structural polysaccharides of fungal cell wall, glucan accounts for about $50-60 \%$ of the cell wall by dry weight (Free 2013). The $\beta$-1,3-glucan, mixed $\beta-1,3-1,4$-glucan, $\beta-1,6$ - and $\alpha-1,3$-glucan are present in fungal cell wall. The major cell wall glucan is $\beta-1,3$-glucan which constitutes about $65-90 \%$ in content (Fontaine et al. 2000; Klis et al. 2001; Aimanianda et al. 2009; Grun et al. 2005). Chitin is a homopolymer of $\beta$ 1,4- $N$-acetylglucosamine, making up approximately $1 \%$ $15 \%$ of the cell wall content (Free 2013).

In bacteria, peptidoglycan is the central component of cell wall. The peptidoglycan not only maintains the shape of bacterial cell, but also confers strength to counteract the osmotic turgor (Smith 2006; Vollmer et al. 2008). The bacterial peptidoglycan is composed of linear glycan crosslinked with short polypeptides (Fisher and Mobashery 2020). Specifically, the glycan strands are composed of alternating $\mathrm{N}$-acetylglucosamine and $\mathrm{N}$-acetylmuramic acid residues. The D-lactoyl group of $\mathrm{N}$-acetylmuramic acid residue is further substituted by a peptide stem (Vollmer et al. 2008). In the gram-negative bacteria, a thin peptidoglycan layer is enclosed by two lipid bilayer membranes. In contrast, the gram-positive bacteria only contain a single membrane surrounded by a more cross-linked and thicker peptidoglycan layer (Shaku et al. 2020).

\section{Regulation of different cell wall components on plant immunity}

Alterations in the composition, or structure of the cell wall have been demonstrated to affect plant resistance against biotic stresses. Here we summarize the plant 


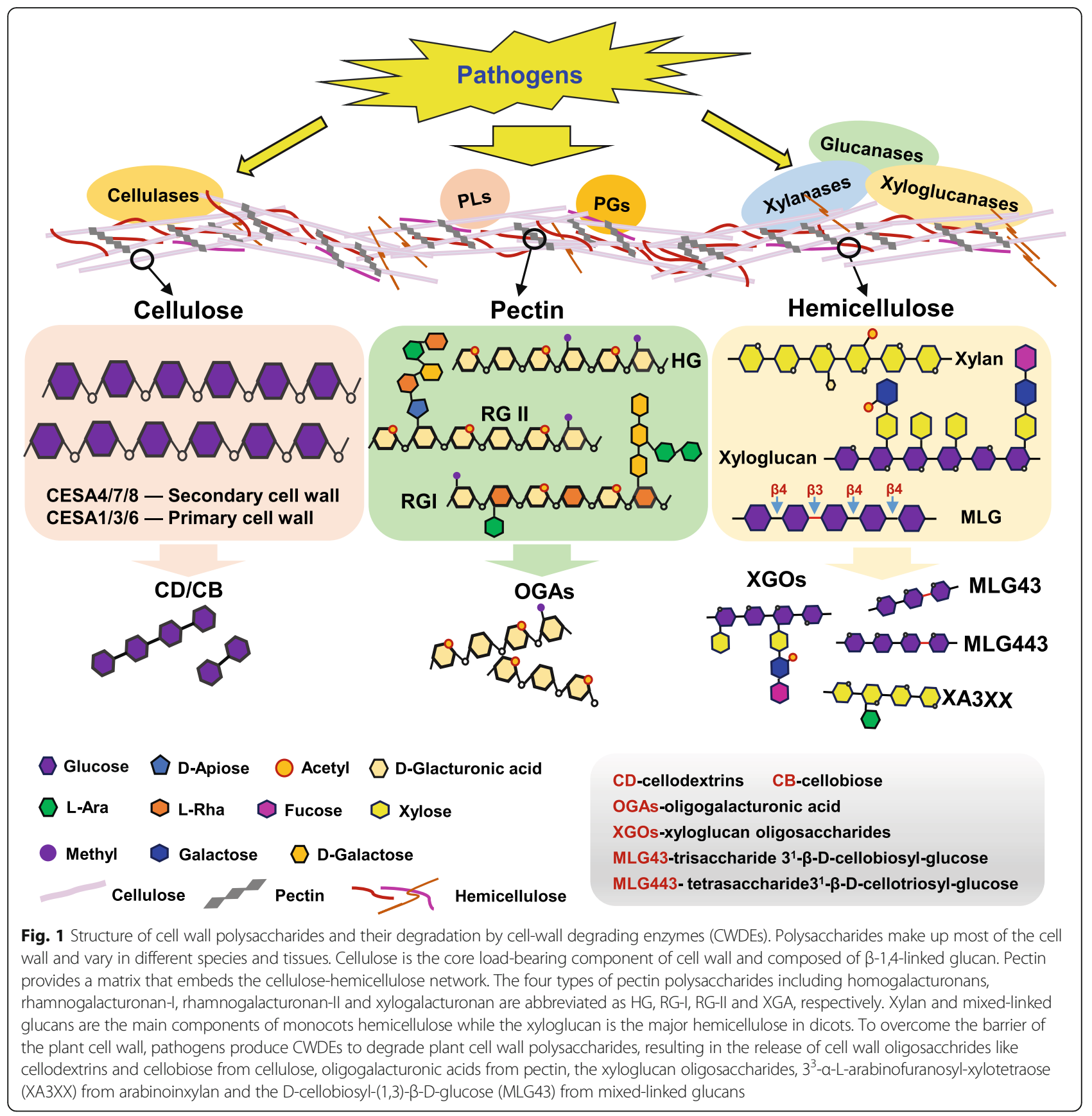

disease phenotypes caused by alteration of cell wall polysaccharides and the underlying mechanisms (Additional file 1: Table 1).

\section{CWI maintenance and plant immunity}

CWI impairment is usually caused by damage in the physical structure of cell wall during development or exposure to diverse stresses. Upon the invasion of pathogens, CWI system perceives the changes of cell wall status to activate defense responses (Gigli-Bisceglia et al. 2020). Several families of plant protein are involved in detecting cell wall damage (Bacete and Hamann 2020). The leucine-rich repeat receptor kinase MIK2 is an important regulator of CWI triggered by cellulose biosynthesis inhibition (Van der Does et al. 2017). MIK2 affects disease resistance, as the mutant mik2-1 exhibits decreased resistance to the fungal pathogen Fusarium oxysporum. (Van der Does et al. 2017). THE1, a member of Catharanthus roseus Receptor Like Kinase 1-like (CrRLK1L) protein family, is originally identified in response to the CWI impairment caused by the reduction of cellulose (Hematy et al. 2007). THE1 functions upstream of GEF4 (Guanosine nucleotide exchange 
factors 4) to positively regulate defenses responses of Arabidopsis against Botrytis cinerea infection (Qu et al. 2017).

As another member of the CrRLK1L family, FER positively regulates the PAMP-triggered immunity through the CWI pathway. The extracellular domain of FER is able to bind to pectin-derived cell wall fragments in vitro (Lin et al. 2018). FER also acts as the receptor for rapid alkalinization factors peptides related to the alkalinization and growth inhibition (Haruta et al. 2014; Stegmann et al. 2017). The fer-4 mutant displays enhanced resistance against $F$. oxysporum, indicating the negative regulation of FER on defending fungal infection (Masachis et al. 2016). However, FER positively regulates defense against Pseudomonas syringae by promoting the formation between FLS2 (Flagellin sensitive2)/EFP (Elongation factor tu receptor) and their co-receptor BAK1 (Brassinosteroid insensitive 1-associated kinase1) (Stegmann et al. 2017). ANX1 and ANX2 are two extra members of CrRLK1L family. Theynegatively regulate PTI and NLR-mediated immunity. Specifically, anx1, anx2 and anx1 anx2 mutants show increased resistance to $P$. syringae due to ROS accumulation and MAPK activation (Mang et al. 2017).

\section{Impact of cellulose on plant immunity}

In higher plants, cellulose is synthesized by a cellulose synthase complex, which is usually located on plasma membrane as heterohexamer in the form of rosette architecture (Desprez et al. 2007). Each unit of hexamer composes of six catalytic submits abbreviated as CESAs, and requires at least three different CESAs to work synergistically to produce cellulose (Desprez et al. 2007). A full cellulose synthase complex therefore contains 36 cellulose synthase. CESA1, CESA3 and CESA6 are responsible for synthetizing cellulose in the primary cell wall, while CESA4, CESA7 and CESA8 are involved in the production of secondary cell wall cellulose (Somerville 2006; Robert et al. 2004; Persson et al. 2007; Taylor et al. 2004).

As the central component of cell wall, cellulose affects both growth and defense response of plants. Plant mutants impaired in cellulose synthesis exhibit severe developmental defects such as dwarfing and reduced yield. In most cases, those mutants are increased in disease resistance, indicating the trade-offs between growth and disease resistance (Schulze et al. 2010; Ramirez et al. 2011). For example, the Arabidopsis mutant irx5/3/1 (irregular xylem) correspondingly disrupted with the CESA4/7/8, displays structural changes in the secondary cell wall and enhanced disease resistance against the bacterial pathogen Ralstonia solanacearum and necrotrophic fungal pathogen Plectosphaerella cucumerina (HernandezBlanco et al. 2007). The expression of CESA4/7/8 is positively regulated by a transcription factor $M Y B 46$. In consistence with the role of $C E S A 4 / 7 / 8$ on plant disease resistance, loss-of-function of MYB46 increases disease resistance of Arabidopsis to $B$. cinerea (Ramirez et al. 2011). In few cases, however, blockage in cellulose synthesis decreases plant disease resistance. For instance, when silenced for HvCSLD2 encoding cellulosesynthase-like D, barley displays reduced cellulose content in epidermal cell wall and its papillae is more easily penetrated by fungus Blumeria graminis, thereby leading to compromised resistance to the powdery mildew (Douchkov et al. 2016).

The impairment of cellulose can activate defense responses such as hormones and callose deposition. CESA3-deficient mutant of Arabidopsis shows increased resistance against $P$. syringae, $B$. cinerea and Erysiphe cichoracearum and it is activated in both ethylene (ET) and jasmonic acid (JA) signaling pathways (HernandezBlanco et al. 2007; Ellis et al. 2002). In tomato, the endo$\beta$-1,4-glucanase family proteins Cel1 and Cel 2 negatively regulates resistance against $B$. cinerea. Their regulation is associated to SA- and JA-dependent defenses (Flors et al. 2007). Another endo- $\beta-1,4$ glucanase, encoded by KORRIGAN1 in Arabidopsis, is involved in disease response to pathogens, as shown by the fact that the mutant kor1-1 lacking KORRIGAN1 is more susceptible to infection by $P$. syringae and accumulates more JA than wild type plant upon infection (Lopez-Cruz et al. 2014). Chemical inhibition of cellulose synthesis also leads to the production of JA, ROS and the deposition of lignin to affect plant immunity (Ellis et al. 2002; Mélida et al. 2015; Hamann et al. 2009).

\section{The hemicellulose-mediated plant immunity}

Xylan and xyloglucan both belong to hemicellulose and are also main components of the plant cell wall. Growing evidence demonstrates that changes in xylan or xyloglucan affect disease resistance of Arabidopsis to pathogens (Delgado-Cerezo et al. 2012; Sampedro et al. 2010; Chowdhury et al. 2017). The Arabidopsis mutants det3 (de-etiolated3) and irx6-1 (irregular xylem 6-1) mutants contain more xylose in the cell wall than that of the wild type. These mutants are both enhanced in resistance to the necrotic fungus $P$. cucumerina (DelgadoCerezo et al. 2012; Rogers et al. 2005; Brown et al. 2005). The Arabidopsis xyl1-2 mutant lacking an $\alpha$ xylosidase displays modified xyloglucan modification and is increased in resistance to $P$. cucumerina (Delgado-Cerezo et al. 2012; Sampedro et al. 2010). Similarly, overexpression of xylan synthesis-related glycosyltransferase in barley improves the resistance against powdery mildew (Chowdhury et al. 2017). Moreover, the heterotrimeric G-protein subunits G $\beta$ (encoded by $A G B 1$ ) and $\mathrm{G} \gamma$ (encoded by $A G G 1 / A G G 2$ ) are both crucial for maintaining xylose content in the cell wall of Arabidopsis; their corresponding deletion 
mutants $a g b 1-2$ and agg1 agg2 are reduced in resistance to several pathogens (Delgado-Cerezo et al. 2012; Brenya et al. 2016; Trusov et al. 2006).

Hemicellulose polysaccharides, such as xylan and xyloglucan, often undergo acetylation to regulate plant development (Pauly et al. 2001). At least two protein families, viz the reduced wall acetylation (RWA) and trichiome birefringence-like (TBL) families, are involved in the acetylation of hemicellulose (Manabe et al. 2011; Gille et al. 2011). RWA family proteins function as $O$ acetyltransferase at the initial stage of acetylation on hemicellulose and other polysaccharides (Manabe et al. 2013). The TBL family proteins tend to acetylate specific polysaccharides compared to RWA proteins (Gille et al. 2011; Xiong et al. 2013; Yuan et al. 2013; Gao et al. 2017; Stranne et al. 2018). However, how RWA and TBL proteins function together is still unclear, it seems more likely that RWA proteins produce acetylated intermediate products which act as substrates of TBL proteins (Persson et al. 2007).

Hemicellulose acetylation affects biotic invasion by determining the cross-link of polysaccharides in the cell wall (Gille and Pauly 2012). In Arabidopsis, the rwa2 mutant is deficient in a potential $O$-acetyltransferase and displays increased resistance to $B$. cinerea (Manabe et al. 2011). The mutant pmr5 (powdery mildew resistant 5) is down-regulated in TBL44 gene expression, leading to significant increase in resistance to powdery mildew but unaltered resistance to Pseudomonas. syringae (Gille et al. 2011; Vogel et al. 2004; Engelsdorf et al. 2017). A TBL member gene ESK1 encodes an $O$-acetyltransferase involved in xylan acetylation in Arabidopsis. The esk 1 mutant shows reduction in xylan acetylation and is increased in resistance against $P$. cucumerina (Urbanowicz et al. 2014; Escudero et al. 2017). With respect to rice, $O s T B L 1$ and OsTBL2 are co-expressed with many $P R$ genes, and their double deletion mutant $t b l 1 t b l 2$ is reduced in resistance to leaf blight disease (Gao et al. 2017). A recent study showed that in face of insectinduced damage, JA signaling is activated in Arabidopsis and expression of AtTBL37 is elevated, consequently increasing acetylated polysaccharides to thicken secondary cell wall and enhance resistance against herbivore (Sun et al. 2020).

Xylan acetyl esterase (AnAXE) derived from the fungus Aspergillus nidulans also contributes to plant disease resistance, because overexpression of $A n A X E$ in either Arabidopsis or Brachypodium distachyon reduces the degree of cell wall acetylation but increases plant resistance to fungal pathogens B. cinerea and Bipolaris sorokiniana (Pogorelko et al. 2013). However, transgenic Arabidopsis and $B$. distachyon overexpressing AnAXE has no effect on resistance against neither the bacterial pathogen $P$. syringae nor Xanthomonas oryzae
(Pogorelko et al. 2013). These also suggest that expression of AnAXE in dicotyledon and monocotyledon triggers different disease resistance responses to deal with fungal and bacterial pathogens.

\section{Effect of pectin on plant immunity}

After pathogens break the outmost cutin layer of plant epicuticle, pectin serves as the first barrier to prevent invasion. Owing to this fact, alterations in pectin component or modification affect plant disease response. UDP-Dglucuronate 4-epimerase (GAE) controls pectin content by catalyzing epimerization of UDP- $\alpha$-D-glucuronic acid to produce the monomeric precursor of pectin UDP- $\alpha-D-$ galacturonic acid (Gu and Bar-Peled 2004). In Arabidopsis, the gae1 gae6 double mutant is impaired in producing pectin homogalacturonan and rhamnogalacturonan-I (Bethke et al. 2016). This mutant displays defects in resistance to pathogens including $P$. syringae and $B$. cinerea, and is hyper-responsive to the hormone jasmonic acid, indicating a link between pectin-mediated disease resistance and JA signaling. Pectin content of Arabidopsis is increased in the mutants pmr5 and pmr6, conferring the mutants with enhanced disease resistance by reducing penetration of powdery mildew fungus (Vogel et al. 2004; Vogel et al. 2002). Similarly, the Arabidopsis mutant mur8-1, which is deficient in 4-GalA linkage, shows reduction in content of pectin rhamnogalacturonan-I and is therefore hyper-susceptible to the hemibiotrophic fungus Colletotrichum higginsianum (Engelsdorf et al. 2017; Mertz et al. 2012). In Arabidopsis, a polygalacturonase encoding gene ADPG2 catalyzes depolymerization of homogalacturonan to negatively regulates disease resistance against the bacterial pathogen $P$. syringae (Wang et al. 2017).

Pectin is generally secreted from the Golgi apparatus to the cell wall in a highly methylated form. Pectin methylesterases (PMEs) remove the methyl group of homogalacturonan during incorporation of pectin into the cell wall (Harholt et al. 2010; Sterling et al. 2001). It has been suggested that highly-methylated pectin shows well tolerance to the attack by cell-wall degrading enzymes (CWDEs) secreted by pathogens, thus conferring plant with disease resistance (Raiola et al. 2010). For instance, PME3 disruption in Arabidopsis increases pectin methylesterification and enhances resistance to $B$. cinerea and Pectobacterium carotovorum due to less colonization of the two pathogens (McMillan et al. 1993); the degree of methylesterification in potato cultivars is positively correlated with their resistance to $P$. carotovorum (Lionetti et al. 2012). Because plants with increased methylesterification of pectin often possess enhanced resistance against pectinase released by pathogens, increasing pectin methylesterification is an ideal breeding strategy to improve crop disease resistance. 
The expression of pectin methylesterase is subjected to post-transcriptional regulation by pectin methylesterase inhibitor (PMEI) (Wolf et al. 2009). Overexpression of PMEI has been shown to enhance plant resistance against various pathogens including fungi, bacteria and viruses (Lionetti et al. 2007; Lionetti et al. 2014). When overexpressing PMEI1 and PMEI2, Arabidopsis displays resistance to both powdery mildew and soft rot disease owing to increased pectin methylesterification (Lionetti et al. 2007). Similarly, heterogenous overexpression of kiwi PMEI enhances wheat resistance against $B$. sorokiniana and Fusarium graminearum (Volpi et al. 2011). In contrast, Arabidopsis overexpressing PMEI are extremely sensitive to virus infection (Lionetti et al. 2014). These studies demonstrate that modification of pectin such as methylesterification can modulate plant disease resistance and suggest that different degrees of pectin methylesterification have different effects on disease resistance.

PMEI can also act against microbial enzymes. CaPMEI1 from pepper (Capsicum annuum) exhibits antifungal activity in vitro against $F$. oxysporum f. sp. matthiole, Alternaria brassicicola, and B. cinerea (An et al. 2008). Virus-induced silencing of CaPMEI1 confers pepper with decreased resistance to $X$. campestris pv. vesicatoria (An et al. 2008). In cotton (Gossypium hirsutum), GhPMEI3 efficiently inhibits the activity of GhPME2/ GhPME31 and is able to increase cotton resistance to Verticillium dahlia via repressing the expression of a fungal polygalacturonase encoding gene VdPG1 (Liu et al. 2018). In Arabidopsis, PMEI13 is regarded as a resistance factor against aphid infestation by influencing the degree of plant pectin methylesterification during aphid settling and feeding (Silva-Sanzana et al. 2019).

Pectin harbors another important modification called acetylation which occurs during pectin exocytosis during its incorporation into the cell wall (Scheller and Ulvskov 2010; Pauly and Scheller 2000). Two types of enzymes modulate acetylation degree of pectin. Pectin acetyltransferases is the first one transferring acetyl residues to polysacchrides, while pectin acetylesterase (PAE) is the other one cleaving acetyl groups from pectin such as galacturonic acid (Manabe et al. 2011; Lee et al. 2011; Bordenave et al. 1995). There is paucity of evidence showing the involvement of pectin acetylation in response to plant biotic stresses. PAE4 and PAE2 may play a role in plant defense (Philippe et al. 2017). PAE4 expression is upregulated in Arabidopsis challenged with $B$. cinerea, Hyaloperonospora arabidopsis and Phytophthora infestans. PAE2 is similarly induced in expression upon biotic stress. A recent study showed that pectin acetylesterases CsPAE2 negatively regulates Citrus sinensis resistance against bacterial canker disease, because knocking-down CsPAE2 allows the disease agent Xanthomonas, citri to proliferate rapidly in citrus (Li et al. 2020a).

\section{Lignin-associated disease resistance}

Lignin, a hydrophobic aromatic polymer, is usually present on the secondary cell wall of vascular plants (Chen and Dixon 2007). The phenylala-nine ammonialyase PAL1 acts as the first enzyme to produce precursors for lignin biosynthesis (Miedes et al. 2014). There are four members of $P A L$ genes in Arabidopsis. Among these members, PAL1 and PAL2 have redundant function. Both the pal1 pal2 double mutant and pal1 pal2 pal3 pal4 quadruple mutant exhibit significant reduction in lignin accumulation and decreased resistance to $P$. syringae (Raes et al. 2003; Huang et al. 2010; Rohde et al. 2004). In rice, OsPAL1 mRNA is accumulated in the $b s r-k 1$ mutant which is disrupted of a tetratricopeptide repeats (TPRs)-containing protein required for modulating turnover of OsPAL1 mRNA (Zhou et al. 2018). The elevated amounts of OsPAL1 mRNA in the $b s r-k 1$ mutant leads to enhanced lignin content and confers broad-spectrum resistance to blast disease and bacterial leaf blight, which is caused by fungal pathogen Magnaporthe oryzae and X. oryzae respectively (Zhou et al. 2018).

Lignin content is typically positively correlated with plant disease resistance. Higher lignification of the cell wall has been observed in plants exposed to pathogen infection or deficient in cellulose biosynthesis, thereby increasing mechanical strength of the plant cell wall and improving tolerance of the cell wall towards CWDEs released by pathogens (Hernandez-Blanco et al. 2007; Huckelhoven 2007). The rice transcription factor OsMYB30 is able to activate the expression of lignin biosynthesis-associated genes Os4CL3 and Os4CL5, resulting in accumulation of lignin subunits $\mathrm{G}$ and $\mathrm{S}$ to strengthen the sclerenchyma cell and resist $M$. oryzae penetration ( $\mathrm{Li}$ et al. 2020b). However, there is also a scenario in which lignin content is negatively related to disease resistance. Down-regulation of lignin in the Medicago sativa $L$. by disrupting the gene encoding shikimate hydroxycinnamoyl transferase (HCT) increases alfalfa resistance against Colletotrichum trifolli, owing to activation in the defense response as manifested by the increase of pectin fragments release, up-regulation of $P R$ genes and elevation of phytohormone levels (Gallego-Giraldo et al. 2011). In cotton, MYB4 functions as a negative regulator of lignin biosynthesis. When heterogeously expressed in Arabidopsis, MYB4 reduces lignin production and promotes release of oligogalacturonides, thereby activating JA biosynthesis and defense responses to confer enhanced disease resistance against the soil-borne fungus $V$. dahliae (Xiao et al. 2021).

\section{Cell wall-derived oligosaccharides as signaling molecules to trigger plant immunity}

To gain access into plant cytoplasm and facilitate infection, pathogens need to degrade the plant cell wall, which requires production of a series of CWDEs 
including cellulase, pectinase, xylanase and xyloglucanase (Fig. 1) (Mary Wanjiru et al. 2002; Lev and Horwitz 2003; Gomez-Gomez et al. 2001; Niture et al. 2006). To combat pathogenic infection, plants have evolved to perceive cell wall fragments released by pathogens for activating defense responses (Jones and Dangl 2006). Those cell wall fragments, released in the form of various oligosaccharides, serve as elicitors of plant immunity (Fig. 2).

\section{The role of CWDEs in pathogenicity}

CWDEs are important for pathogens to breach the plant cell wall without penetration structures or at the late stage of invasion for necrotrophic pathogens (Niture et al. 2006). Considering the complexity of the plant cell wall, it is reasonable that plant pathogens have to produce a set of carbohydrateactive enzymes specifically to degrade plant polysaccharides. At the early stage of invasion, pathogens including B. cinerea, Aspergillus flavus and Colletotrichum gloeosporioides produce polygalacturonase and pectate lyase to depolymerize homogalacturonan of pectin for exposing polysaccharides (D'Ovidio et al. 2004; Lombard et al. 2010; Blanco-Ulate et al. 2014; Kubicek et al. 2014; Yakoby et al. 2000). Other cell-wall degrading enzymes including cellulase, xylanase and xyloglucanase are also able to promote pathogenic infection by degrading cellulose and hemicellulose (van den Brink and de Vries 2011).

Oligosaccharides released from plant cell wall by degradation of polysaccharides can elicit plant defense responses. For example, two endoglucanases MoCel12A/B, belonging to glycosyl hydrolases family GH12, are secreted by $M$. ory$z a e$ during infection and are able to degrade rice cell wall mixed-linked glucans. This degradation then releases trisaccharide $3^{1}-\beta$-D-cellobiosyl-glucose (G4G3G) and tetrasaccharide $3^{1}-\beta$-D-cellotriosyl-glucose (G4G4G3G). G4G3G and G4G4G3G are subsequently perceived by the rice OsCERK1-OsCEBiP complex to promote ROS burst, MAPK activation and the expression of immune-responsive genes for enhancing disease resistance (Yang et al. 2021).

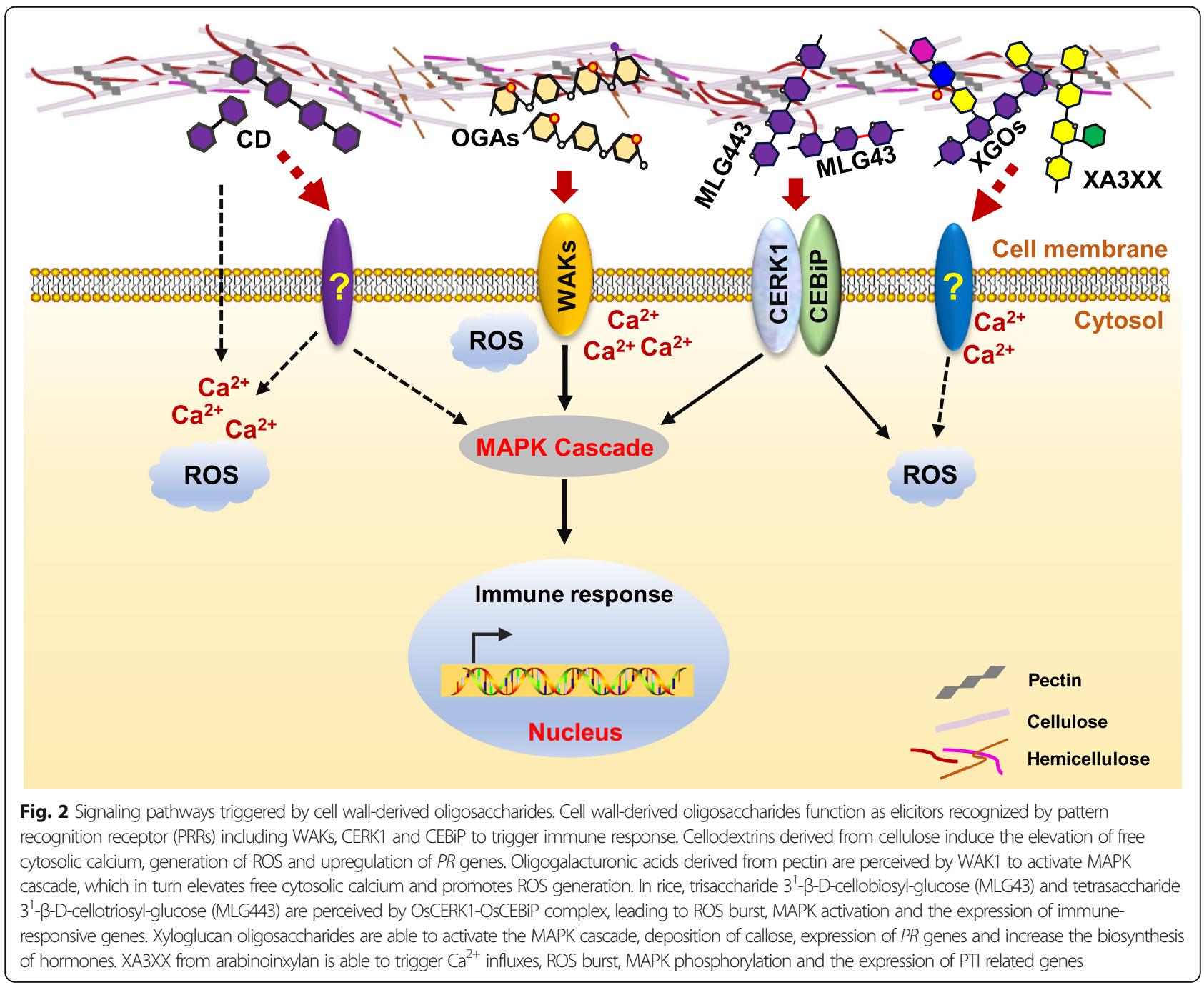


Accordingly, M. oryzae mutant disrupted with MoCel12A/B are increased in pathogenicity as a result of reduced host immune response (Yang et al. 2021).

In addition to degrading the cell wall, CWDEs also function as effectors to either repress or elicit plant immunity. During infection of rice host, the blast fungus $M$. oryzae secretes a glycosyl hydrolase family 61 protein MoCDIP4 to target the OsDjA9-OsDRP1E protein complex for damping rice immunity. Loss of MoCDIP4 increases fungal pathogenicity due to reduced ability to repress rice immunity (Xu et al. 2020). Five polygalacturonases including BcPG2, BcPG3, BcPG4 and BcPG6 from $B$. cinerea, as well as AnPGB from $A$. niger, are recognized by a leucine-rich repeat receptor-like protein RLP42 in Arabidopsis (Zhang et al. 2014). A xyloglucanspecific endoglucanase PsXEG1 is secreted by Phytophthora sojae into the plant apoplast and is recognized by a LRR receptor-like protein response to XEG1 (RXEG1) in Nicotiana benthamiana to activate defense response (Wang et al. 2018; Ma et al. 2017). However, the elicitor activity of PsXEG1 does not depend on its xyloglucanase activity (Ma et al. 2015).

\section{Cellulose-derived oligosaccharide cellodextrins}

Cellodextrins are oligomers derived from cellulose and composed of $\beta-1,4$ glucoside residues. According to their degree of oligomerization, cellodextrins are present in the form of cellobiose, cellotriose, cellotetraose etc. The polymerization degree of cellodextrins is closely related to their biological activity in eliciting immune response. Cellodextrins are capable of inducing defense responses in grapevine (Vitis vinifera L.) including oxidative burst, elevation in free cytosolic calcium and the expression of $P R$ genes, thereby enhancing grapevine resistance against B. cinerea (Aziz et al. 2007). The cellotriose derived from the endophytic fungus Piriformospora indica induces the elevation of calcium, production of reactive oxygen species, changes in membrane potential, and the expression of defense-related genes including RBOHD, MPK3, NPR1 and LOX1 (Johnson et al. 2018). Pretreatment of Arabidopsis with cellobiose increases resistance to $P$. syringae due to the induction of immune responses including elevation of intracellular calcium, activation of MAPK cascades, but not the generation of ROS or deposition of callose (Souza et al. 2017). Upon treatment with cellobiose, cellotriose, or cellotetraose, the typical biotic response gene WRKY30 is expressed at a similar level in Arabidopsis (Souza et al. 2017). Recently, cellodextrins are reported to be oxidized by an Arabidopsis berberine bridge enzyme-like (BBE-like) proteinCELLOX (cellodextrin oxidase). Transgenic plants overexpressing CELLOX are increased in resistance against $B$. cinerea because the oxidized cellodextrins are less utilized carbon sources for B. cinerea (Locci et al. 2019).

\section{Hemicellulose-derived oligosaccharides}

Xyloglucan has also been characterized as potent elicitor of plant immunity. Xyloglucan-derived oligosaccharides are able to activate disease resistance against pathogens and trigger a wide range of defense responses. With respect to tobacco, exogenous addition of xyloglucan oligosaccharides accelerates cell elongation and division, as well as expression of defense responsive genes including jasmonate ZIM-domain gene JAZ8 and chitinase-like gene ATHCHIB (Gonzalez-Perez et al. 2014). In addition, exogenous addition of low concentrations of xyloglucan oligosaccharides changes plant's response to abiotic stresses, especially cold damage and flooding stress in vine (Salvador and Lasserre 2010). In Arabidopsis, application of xyloglucan increases plant resistance against $B$. cinerea through inducing the expression of various genes involved in defense response, such as MAPK, callose synthase gene PMR4 and PR genes (Claverie et al. 2018).

In Arabidopsis, the pentasaccharide $3^{3}-\alpha$-L-arabinofuranosyl-xylotetraose (XA3XX) from arabinoxylan is able to trigger immune responses including calcium influx, ROS production, MAPK phosphorylation and expression of PTI-related genes (Melida et al. 2020). Pretreatment with XA3XX confers tomato and pepper with resistance to $P$. syringae and Sclerotinia sclerotiorum (Melida et al. 2020) Mixed-linked glucans, as another main component of poaceae hemicellulose and some microbial cell wall, can promote defense response as XA3XX. For example, pretreatment of D-cellobiosyl-(1, 3)- $\beta$-D-glucose (MLG43) enhances resistance to oomycete $H$. arabidopsidis in Arabidopsis (Rebaque et al. 2021). Similarly, pretreating tomato and pepper with MLG43 before incubation with $P$. syringae and $B$. cinerea respectively confers enhanced resistance (Rebaque et al. 2021)

\section{Pectin-derived oligosaccharides}

The well-studied elicitors derived from plant cell wall are oligogalacturonic acids with different degrees of polymerization produced by degradation of pectin. Oligogalacturonic acids stimulate disease resistance in both grape and Arabidopsis by inducing immune responses including calcium ion flow, accumulation of reactive oxygen species, expression of $P R$ genes and changes in protein profiles in apoplast (Aziz et al. 2004; Casasoli et al. 2008; Denoux et al. 2008; Galletti et al. 2008; Ferrari et al. 2007). Consistent with these findings, Arabidopsis and tobacco overexpressing fungal polygalacturonase are increased in resistance to pathogens such as $B$. cinerea, largely due to polygalacturonase-dependent degradation of pectin and release of oligosaccharide elicitors for activating defense response (Ferrari et al. 2007; Ferrari et al. 2008). In addition to pectin, Arabidopsis expressing a fungal cutinase from Fusarium, solani f. sp., pisi exhibits an 
alteration in cuticle structure and properties and is changed in postgenital organ fusions (Sieber et al. 2000). Further evidence shows that perturbations in the cutincular layer of transgenic Arabidopsis plants confer full resistance against B. cinerea (Sieber et al. 2000; Chassot et al. 2007). This fact could be attributed to the putative products of cuticle upon the reaction of cutinase in triggering defense responses (Chassot et al. 2008).

The plasma membrane associated protein WAK1 has been characterized as the receptor for recognizing oligogalacturonic acids. Its extracellular domain preferentially binds to the de-esterified pectin (Kohorn and Kohorn 2012). Arabidopsis encodes 25 members of the WAK family, among which WAK1 and WAK2 contribute to disease resistance against various pathogens including powdery mildew fungus (Brutus et al. 2010; Kohorn et al. 2009). In rice, overexpression of OsWAK1 improves blast disease resistance ( $\mathrm{Li}$ et al. 2009), and OsWAK91 interacts with OsWAK92 and OsWAK14 to form dimers for regulating disease resistance (Delteil et al. 2016). There are evidences showing the binding capacity of WAK1 with oligogalacturonic acids (Decreux and Messiaen 2005; Decreux et al. 2006), WAK2 may play role in perceiving oligogalacturonic acids, but it needs evidence.

WAK1 is activated by oligogalacturonic acids with a higher degree of polymerization (DP10-15). Short oligogalacturonic acids (DP4-6, DP1-7) can also induce the expression of $P R$ genes in potatoes and tomatoes, despite less effective in activating hormones than long oligogalacturonic acids (Denoux et al. 2008; Ferrari et al. 2007; Davis et al. 1986; Simpson et al. 1998). Very short trimer oligogalacturonic acid DP3 stimulates disease resistance in Arabidopsis at a comparable level as long oligogalacturonic acids. But DP3 results in plant growth retardation (Davidsson et al. 2017). DP3 can promote phosphorylation of MPK3 and MPK6 to trigger immune response without inducing ROS generation (Galletti et al. 2008; Davidsson et al. 2017; Galletti et al. 2011). Partially acetylated oligogalacturonic acids are regarded as more efficient elicitor for activating stress response including the accumulation of phenolic compounds to decrease haustoria formation at the penetration site of B. graminis (Randoux et al. 2010). The presence of oligogalacturonic acids with lower degree of methylesterification enhances the resistance to $B$. cinerea (Osorio et al. 2008).

Oligogalacturonic acids generated during the pathogens infection are increasingly recognized to contribute to plant defense response. The global composition of oligogalacturonic acids has been disclosed in Arabidopsis leaves upon infection with $B$. cinerea (Voxeur et al. 2019). The polymerization degree of oligogalacturonic acids produced by fungal pectin lyases ranges from DP310 , of which mainly are DP4 and DP5. By contrast, the oligogalacturonic acids derived from polygalacturonase are mainly DP2 and DP3, with the DP3 being all methylesterified. Most of the nonmethylesterified oligogalacturonic acids resulted from polygalacturonase are further oxidized probably by OGOX1, a member of Berberine Bridge Enzyme-like (BBE-like) protein family (Voxeur et al. 2019; Benedetti et al. 2018). Oligogalacturonic acids not only participate in immune response, but also regulate the growth and development of plants, because they can inhibit root formation mediated by auxin in Arabidopsis (Savatin et al. 2014). However, it remains largely unknown how oligogalacturonic acidsdependent signaling balances growth and disease response in plants.

\section{Cell wall-derived elicitors' recognition by PRRs}

Pattern-triggered immunity is initiated when PRRs resident on the plant plasma membrane recognize damageassociated molecular pattern (DAMP) or microbeassociated molecular pattern (MAMP). The oligomers of homogalacturonan, cellulose, mix-linked glucans and arabinoxylan and xyloglucan have been reported as DAMPs in plant immunity (Souza et al. 2017; Claverie et al. 2018; Melida et al. 2020; Rebaque et al. 2021; Aziz et al. 2004). Oligogalacturonic acids are the best characterized DAMP. Lysin motif (LYM) PRR, wall-associated kinase (WAK) and lectin-like (Lec) PRR (mainly for bacterial lipopolysaccharides) are the three main families of receptors involved in the perception of carbohydratebased DAMPs or MAMPs (Bacete et al. 2018).

The oligogalacturonic acids are percevied by WAK, which contains an extracellular domain called epidermal growth factor (EGF) motif, a transmembrane domain and an intracellular Ser/Thr kinase domain. The Nterminal part of extracellular domain but not the EGF motif confers pectin binding capacity (Brutus et al. 2010) Only WAK1 has been experimentally demonstrated as the oligogalacturonic acids receptor in vivo at present (Kohorn and Kohorn 2012). Recently, MLG trisaccharide and tetrasaccharide derived from the rice cell wall have been characterized as novel DAMPs perceived by OsCERK1 and OsCEBiP complex (Yang et al. 2021). MLG trisaccharide is reported to trigger PTI responses partially dependent on CERK1, LYK4 and LYK5 (Rebaque et al. 2021). To date, it remains ambiguous which PRRs detect cellulose-derived oligomers $\beta$-1,4-glucans, xyloglucan oligosaccharides and the pentasaccharide of arabinoxylan.

In the course of host-pathogen interaction, the plant can secrete hydrolytic enzymes such as glucanases and chitinases to degrade the cell wall of pathogens. The disrupted fungal cell wall then releases fragments functioning as MAMP to active plant immune responses (Rovenich et al. 2016). Fugal chitin is a well- 
characterized MAMP (Rovenich et al. 2016). In Arabidopsis, CERK1, together with LYK4 and LYK5, are required for recognizing of chitin oligosaccharides (Liu et al. 2012; Cao et al. 2014). The perception of chitin oligosaccharides in rice depends on OsCEBiP and OsCERK1. OsCEBiP directly binds to chitin oligomers by its LysM domain and forms a receptor complex with OsCERK1 to induce chitin signaling (Liu et al. 2016; Shimizu et al. 2010). As another main component of fungal cell wall, non-branched $\beta$-1,3-glucans oligosaccharides from $P$. cucumerina is also a MAMP triggering immune responses of Arabidopsis including the elevation in cytoplasmic calcium, phosphorylation of MAPKs, and upregulation of PTI marker genes (Melida et al. 2018). However, AtCERK1 only functions as a co-receptor, because it does not directly bind to oligosaccharides such as 1,3- $\beta-(\mathrm{Glc})_{6}$ (Melida et al. 2018; Del Hierro et al. 2021).

DAMPs have been shown to amplify the MAMPs signaling in Arabidopsis. The differentiated outer cell layer of root maintains low expression of PPRs, thus lacking responses to MAMPs. When encountering damage, the epidermal cell upregulates expression of PRRs such as EFR, CERK1, RLP23, FLS2 and LORE in neighbor cells. The upregulation of PRRs subsequently amplifies MAMP responses (Zhou et al. 2020). Intriguingly, DAMPs alone do not induce MAMP responses, suggesting that the DAMPs more likely function in damage perception (Zhou et al. 2020). By integrating the signals of damage and MAMPs, plants are capable of distinguishing non-pathogenic microbes from pathogenic ones (Zhou et al. 2020).

\section{Conclusion remarks and perspectives}

The cell wall varies in both component and structure between different plant species and developmental stages. It undergoes dynamic remodeling throughout plant growth and functions as effective physical barrier to defend against diverse biotic stresses. The cell wall components, including cellulose, hemicellulose, pectin and lignin, are crucial for plant immunity, because mutation of genes associated with either biosynthesis or modification of cell wall leads to changes in disease resistance in many plant species. Besides, cellodextrin, oligogalacturonic acid and xyloglucan oligosaccharide, and those released from cell wall infected by pathogens, have been characterized as potent elicitors or signaling molecules to increase plant disease resistance.

Despite a critical link has been established between the plant cell wall and immunity, there still exist many unknowns regarding molecular regulations of cell wall on immunity throughout plant kingdom. On one hand, it remains ambiguous how plant changes or modifies its cell wall to deal with microbial infection and the underlying mechanisms are largely unknown. On the other hand, it is interesting to determine whether there is a common strategy or specific strategy employed by plants to remodel cell wall for tackling attacks of different types of pathogens. Furthermore, our knowledge on cell wall associated immunity are mostly obtained by studying the model plant Arabidopsis. Less is known about several crops such as rice, wheat and maize.

Increasing number of sequenced crop genomes are available now. The state-of-art biophysical, biochemical and genetic techniques such as CRISPR have been developed. These technical advancements have offered great opportunity to decipher the regulatory role of cell wall modification and composition on plant immunity from a comprehensive and in-depth perspective. Nowadays, it is becoming easier to identify the genes involved in cell wall biosynthesis and modification, allowing us to dissect their regulatory mechanisms on plant disease resistance. Our efforts on studying plant cell wall on immunity will provide not only gene resources, but also fundamental knowledge to develop novel strategies for practically breeding crop cultivars with enhanced disease resistance.

\section{Supplementary Information}

The online version contains supplementary material available at https://doi. org/10.1007/s44154-021-00003-4

Additional file 1: Table 1. Cell wall alteation and corresponding phenotypes against disease.

Acknowledgments

We thank Dr. Xiaobo Zhu for his help on preparing the figures.

Code availability

Not applicable

Authors' contributions

This work was supervised by Xuewei Chen. The original draft was prepared by Jiangxue Wan and Min He, and revised by Xuewei Chen. Qingqing Hou drew the figures. Lijuan Zou, Yihua Yang and Yan Wei collected data and made the table. The author(s) read and approved the final manuscript.

\section{Funding}

This work was supported by grants from the National Natural Science Foundation of China (NSFC) (grant no. 31825022 and 31772153), Key Research and Development Program from Sichuan Province (grant no. 2018JZ0072) to Xuewei Chen; NSFC (grant no. 32001523) to Jiangxue Wan; NSFC (grant no. 31871920) and International Cooperation and Exchange Program of Sichuan Science and Technology Department (grant no. 2020YFH0137) to Min He.

Availability of data and materials Not applicable

\section{Declarations}

Ethics approval consent to participate Not applicable

Consent for publication Not applicable 


\section{Competing interests}

Author Xuewei Chen is a member of the Editorial Board and was not involved in the journal's review of, or decisions related to, this manuscript.

\section{Author details}

'State Key Laboratory of Crop Gene Exploration and Utilization in Southwest China, Sichuan Agricultural University at Wenjiang, Chengdu 611130, Sichuan, China. ${ }^{2}$ Ecological Security and Protection Key Laboratory of Sichuan Province, Mianyang Normal University, Mianyang 621000, Sichuan, China.

\section{Received: 30 April 2021 Accepted: 13 July 2021}

\section{Published online: 18 August 2021}

\section{References}

Aimanianda V, Clavaud C, Simenel C, Fontaine T, Delepierre M, Latge JP (2009) Cell wall $\beta-(1,6)$-glucan of Saccharomyces cerevisiae: structural characterization and in situ synthesis. J Biol Chem. 284(20):13401-13412. https://doi.org/10.1 074/jbc.M807667200

An SH, Sohn KH, Choi HW, Hwang IS, Lee SC, Hwang BK (2008) Pepper pectin methylesterase inhibitor protein CaPMEl1 is required for antifungal activity, basal disease resistance and abiotic stress tolerance. Planta. 228(1):61-78. https://doi.org/10.1007/s00425-008-0719-z

Arana DM, Prieto D, Roman E, Nombela C, Alonso-Monge R, Pla J (2009) The role of the cell wall in fungal pathogenesis. Microb Biotechnol. 2(3):308-320. https://doi.org/10.1111/j.1751-7915.2008.00070.x

Aziz A, Gauthier A, Bezier A, Poinssot B, Joubert JM, Pugin A et al (2007) Elicitor and resistance-inducing activities of $\beta-1,4$ cellodextrins in grapevine, comparison with $\beta-1,3$ glucans and a-1,4 oligogalacturonides. J Exp Bot. 58(6):1463-1472. https://doi.org/10.1093/jxb/erm008

Aziz A, Heyraud A, Lambert B (2004) Oligogalacturonide signal transduction, induction of defense-related responses and protection of grapevine against Botrytis cinerea. Planta. 218(5):767-774. https://doi.org/10.1007/s00425-003-1153-x

Bacete L, Hamann T (2020) The Role of mechanoperception in plant cell wall integrity maintenance. Plants (Basel) 9(5). https://doi.org/10.3390/pla nts9050574

Bacete L, Melida H, Miedes E, Molina A (2018) Plant cell wall-mediated immunity: cell wall changes trigger disease resistance responses. Plant J. 93(4):614-636. https://doi.org/10.1111/tpj.13807

Benedetti M, Verrascina I, Pontiggia D, Locci F, Mattei B, De Lorenzo G et al (2018) Four Arabidopsis berberine bridge enzyme-like proteins are specific oxidases that inactivate the elicitor-active oligogalacturonides. Plant J. 94(2): 260-273. https://doi.org/10.1111/tpj.13852

Bethke G, Thao A, Xiong G, Li B, Soltis NE, Hatsugai N et al (2016) Pectin biosynthesis is critical for cell wall integrity and immunity in Arabidopsis thaliana. Plant Cell. 28(2):537-556. https://doi.org/10.1105/tpc.15.00404

Blanco-Ulate B, Morales-Cruz A, Amrine KC, Labavitch JM, Powell AL, Cantu D (2014) Genome-wide transcriptional profiling of Botrytis cinerea genes targeting plant cell walls during infections of different hosts. Front Plant Sci. 5:435. https://doi.org/10.3389/fpls.2014.00435

Bordenave M, Goldberg R, Huet JC, Pernollet JC (1995) A novel protein from mung bean hypocotyl cell walls with acetyl esterase activity. Phytochemistry. 38(2):315-319. https://doi.org/10.1016/0031-9422(94)00647-C

Brenya E, Trusov Y, Dietzgen RG, Botella JR (2016) Heterotrimeric G-proteins facilitate resistance to plant pathogenic viruses in Arabidopsis thaliana (L.) Heynh. Plant Signal Behav 11(8):e1212798. https://doi.org/10.1080/15592324.2 016.1212798

Brown DM, Zeef LA, Ellis J, Goodacre R, Turner SR (2005) Identification of novel genes in Arabidopsis involved in secondary cell wall formation using expression profiling and reverse genetics. Plant Cell. 17(8):2281-2295. https:// doi.org/10.1105/tpc.105.031542

Brutus A, Sicilia F, Macone A, Cervone F, De Lorenzo G (2010) A domain swap approach reveals a role of the plant wall-associated kinase 1 (WAK1) as a receptor of oligogalacturonides. Proc Natl Acad Sci USA. 107(20):9452-9457. https://doi.org/10.1073/pnas.1000675107

Caffall KH, Mohnen D (2009) The structure, function, and biosynthesis of plant cell wall pectic polysaccharides. Carbohydr Res. 344(14):1879-1900. https:// doi.org/10.1016/j.carres.2009.05.021

Cao Y, Liang Y, Tanaka K, Nguyen CT, Jedrzejczak RP, Joachimiak A et al (2014) The kinase LYK5 is a major chitin receptor in Arabidopsis and forms a chitin- induced complex with related kinase CERK1. Elife. 3. https://doi.org/10.7554/ eLife.03766

Carpita NC, Gibeaut DM (1993) Structural models of primary cell walls in flowering plants: consistency of molecular structure with the physical properties of the walls during growth. Plant J. 3(1):1-30. https://doi.org/1 0.1111/j.1365-313X.1993.tb00007.x

Casasoli M, Spadoni S, Lilley KS, Cervone F, De Lorenzo G, Mattei B (2008) Identification by 2-D DIGE of apoplastic proteins regulated by oligogalacturonides in Arabidopsis thaliana. Proteomics. 8(5):1042-1054 https://doi.org/10.1002/pmic.200700523

Chassot C, Nawrath C, Metraux JP (2007) Cuticular defects lead to full immunity to a major plant pathogen. Plant J. 49(6):972-980. https://doi.org/10.1111/j.13 65-313X.2006.03017.x

Chassot C, Nawrath C, Métraux JP (2008) The cuticle: not only a barrier for plant defence: A novel defence syndrome in plants with cuticular defects. Plant Signal Behav. 3(2):142-144. https://doi.org/10.4161/psb.3.2.5071

Chen F, Dixon RA (2007) Lignin modification improves fermentable sugar yields for biofuel production. Nat Biotechnol. 25(7):759-761. https://doi.org/10.103 8/nbt1316

Chowdhury J, Luck S, Rajaraman J, Douchkov D, Shirley NJ, Schwerdt JG et al (2017) Altered expression of genes implicated in xylan biosynthesis affects penetration resistance against powdery mildew. Front Plant Sci. 8:445. https://doi.org/10.3389/fpls.2017.00445

Claverie J, Balacey S, Lemaitre-Guillier C, Brule D, Chiltz A, Granet L et al (2018) The cell wall-derived xyloglucan is a new DAMP triggering plant immunity in Vitis vinifera and Arabidopsis thaliana. Front Plant Sci. 9:1725. https://doi.org/1 $0.3389 /$ fpls.2018.01725

Cosgrove DJ (2005) Growth of the plant cell wall. Nat Rev Mol Cell Biol. 6(11): 850-861. https://doi.org/10.1038/nrm1746

Davidsson P, Broberg M, Kariola T, Sipari N, Pirhonen M, Palva ET (2017) Short oligogalacturonides induce pathogen resistance-associated gene expression in Arabidopsis thaliana. BMC Plant Biol. 17(1):19. https://doi.org/10.1186/s12 870-016-0959-1

Davis KR, Darvill AG, Albersheim P, Dell A (1986) Host-Pathogen Interactions. XXIX oligogalacturonides released from sodium polypectate by endopolygalacturonic acid lyase are elicitors of phytoalexins in soybean. Plant Physiol. 80(2):568-577. https://doi.org/10.1104/pp.80.2.568

Decreux A, Messiaen J (2005) Wall-associated kinase WAK1 interacts with cell wall pectins in a calcium-induced conformation. Plant Cell Physiol. 46(2):268-278. https://doi.org/10.1093/pcp/pci026

Decreux A, Thomas A, Spies B, Brasseur R, Cutsem PV, Messiaen J (2006) In vitro characterization of the homogalacturonan-binding domain of the wallassociated kinase WAK1 using site-directed mutagenesis. Phytochemistry. 67(11):1068-1079. https://doi.org/10.1016/j.phytochem.2006.03.009

Del Hierro I, Melida H, Broyart C, Santiago J, Molina A (2021) Computational prediction method to decipher receptor-glycoligand interactions in plant immunity. Plant J. 105(6):1710-1726. https://doi.org/10.1111/tpj.15133

Delgado-Cerezo M, Sanchez-Rodriguez C, Escudero V, Miedes E, Fernandez PV, Jorda L et al (2012) Arabidopsis heterotrimeric G-protein regulates cell wall defense and resistance to necrotrophic fungi. Mol Plant. 5(1):98-114. https:// doi.org/10.1093/mp/ssr082

Delteil A, Gobbato E, Cayrol B, Estevan J, Michel-Romiti C, Dievart A et al (2016) Several wall-associated kinases participate positively and negatively in basal defense against rice blast fungus. BMC Plant Biol. 16:17. https://doi.org/10.11 86/s12870-016-0711-x

Denoux C, Galletti R, Mammarella N, Gopalan S, Werck D, De Lorenzo G et al (2008) Activation of defense response pathways by OGs and Flg22 elicitors in Arabidopsis seedlings. Mol Plant. 1(3):423-445. https://doi.org/10.1093/mp/ssn019

Desprez T, Juraniec M, Crowell EF, Jouy H, Pochylova Z, Parcy F et al (2007) Organization of cellulose synthase complexes involved in primary cell wall synthesis in Arabidopsis thaliana. Proc Natl Acad Sci USA. 104(39):15572. https://doi.org/10.1073/pnas.0706569104

Douchkov D, Lueck S, Hensel G, Kumlehn J, Rajaraman J, Johrde A et al (2016) The barley (Hordeum vulgare) cellulose synthase-like D2 gene (HvCsID2) mediates penetration resistance to host-adapted and nonhost isolates of the powdery mildew fungus. New Phytol. 212(2):421-433. https://doi.org/1 $0.1111 / \mathrm{nph} .14065$

D'Ovidio R, Mattei B, Roberti S, Bellincampi D (2004) Polygalacturonases, polygalacturonase-inhibiting proteins and pectic oligomers in plantpathogen interactions. Biochim Biophys Acta. 1696(2):237-244. https://doi. org/10.1016/j.bbapap.2003.08.012 
Ellis C, Karafyllidis I, Wasternack C, Turner JG (2002) The Arabidopsis mutant cev links cell wall signaling to jasmonate and ethylene responses. Plant Cell. 14(7):1557-1566. https://doi.org/10.1105/tpc.002022

Engelsdorf T, Hamann T (2014) An update on receptor-like kinase involvement in the maintenance of plant cell wall integrity. Ann Bot. 114(6):1339-1347. https://doi.org/10.1093/aob/mcu043

Engelsdorf T, Will C, Hofmann J, Schmitt C, Merritt BB, Rieger L et al (2017) Cell wall composition and penetration resistance against the fungal pathogen Colletotrichum higginsianum are affected by impaired starch turnover in Arabidopsis mutants. J Exp Bot. 68(3):701-713. https://doi.org/10.1093/jxb/ erw434

Escudero V, Jordá L, Sopeña-Torres S, Mélida H, Miedes E, Muñoz-Barrios A et al (2017) Alteration of cell wall xylan acetylation triggers defense responses that counterbalance the immune deficiencies of plants impaired in the $\beta$-subunit of the heterotrimeric G-protein. Plant J. 92(3):386-399. https://doi.org/1 $0.1111 /$ tpj. 13660

Ferrari S, Galletti R, Denoux C, De Lorenzo G, Ausubel FM, Dewdney J (2007) Resistance to Botrytis cinerea induced in Arabidopsis by elicitors is independent of salicylic acid, ethylene, or jasmonate signaling but requires PHYTOALEXIN DEFICIENT3. Plant Physiol. 144(1):367-379. https://doi.org/10.11 04/pp.107.095596

Ferrari S, Galletti R, Pontiggia D, Manfredini C, Lionetti V, Bellincampi D et al (2008) Transgenic expression of a fungal endo-polygalacturonase increases plant resistance to pathogens and reduces auxin sensitivity. Plant Physiol. 146(2):669-681. https://doi.org/10.1104/pp.107.109686

Fisher JF, Mobashery S (2020) Constructing and deconstructing the bacterial cell wall. Protein Sci. 29(3):629-646. https://doi.org/10.1002/pro.3737

Flors V, Leyva Mde L, Vicedo B, Finiti I, Real MD, Garcia-Agustin P et al (2007) Absence of the endo- $\beta-1,4-$ glucanases Cel1 and Cel2 reduces susceptibility to Botrytis cinerea in tomato. Plant J. 52(6):1027-1040. https://doi.org/10.1111/ j.1365-313X.2007.03299.x

Fontaine T, Simenel C, Dubreuca G, Adam O, Delepierre M, Lemoine J et al (2000) Molecular organization of the alkali-insoluble fraction of Aspergillus fumigatus cell wall. J Biol Chem. 275(36):27594-27607. https://doi.org/10.1 074/jbc.M909975199

Free SJ (2013) Fungal cell wall organization and biosynthesis. Adv Genet. 81:3382. https://doi.org/10.1016/B978-0-12-407677-8.00002-6

Gallego-Giraldo L, Jikumaru Y, Kamiya Y, Tang Y, Dixon RA (2011) Selective lignin downregulation leads to constitutive defense response expression in alfalfa (Medicago sativa L.). New Phytol. 190(3):627-639. https://doi.org/10.1111/j.14 69-8137.2010.03621.x

Galletti R, Denoux C, Gambetta S, Dewdney J, Ausubel FM, De Lorenzo G et al (2008) The AtrbohD-mediated oxidative burst elicited by oligogalacturonides in Arabidopsis is dispensable for the activation of defense responses effective against Botrytis cinerea. Plant Physiol. 148(3):1695-1706. https://doi.org/10.11 04/pp.108.127845

Galletti R, Ferrari S, De Lorenzo G (2011) Arabidopsis MPK3 and MPK6 play different roles in basal and oligogalacturonide- or flagellin-induced resistance against Botrytis cinerea. Plant Physiol. 157(2):804-814. https://doi.org/10.1104/ pp.111.174003

Gao Y, He C, Zhang D, Liu X, Xu Z, Tian Y et al (2017) Two trichome birefringence-like proteins mediate xylan acetylation, which is essential for leaf blight resistance in rice. Plant Physiol. 173(1):470-481. https://doi.org/1 $0.1104 / p p .16 .01618$

Gigli-Bisceglia N, Engelsdorf T, Hamann T (2020) Plant cell wall integrity maintenance in model plants and crop species-relevant cell wall components and underlying guiding principles. Cell Mol Life Sci. 77(11): 2049-2077. https://doi.org/10.1007/s00018-019-03388-8

Gille S, de Souza A, Xiong G, Benz M, Cheng K, Schultink A et al (2011) Oacetylation of Arabidopsis hemicellulose xyloglucan requires $A X Y 4$ or $A X Y 4 L$, proteins with a TBL and DUF231 domain. Plant Cell. 23(11):4041-4053. https://doi.org/10.1105/tpc.111.091728

Gille S, Pauly M (2012) O-acetylation of plant cell wall polysaccharides. Front Plant Sci. 3:12. https://doi.org/10.3389/fpls.2012.00012

Glazebrook J (2005) Contrasting mechanisms of defense against biotrophic and necrotrophic pathogens. Annu Rev Phytopathol. 43:205-227. https://doi. org/10.1146/annurev.phyto.43.040204.135923

Gomez-Gomez E, Isabel M, Roncero G, Di Pietro A, Hera C (2001) Molecular

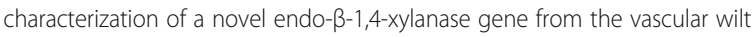
fungus Fusarium oxysporum. Curr Genet. 40(4):268-275. https://doi.org/10.1 007/s00294-001-0260-0
Gonzalez-Perez L, Perrotta L, Acosta A, Orellana E, Spadafora N, Bruno L et al (2014) In tobacco BY-2 cells xyloglucan oligosaccharides alter the expression of genes involved in cell wall metabolism, signalling, stress responses, cell division and transcriptional control. Mol Biol Rep. 41(10):6803-6816. https:// doi.org/10.1007/s11033-014-3566-y

Grun $\mathrm{CH}$, Hochstenbach F, Humbel BM, Verkleij AJ, Sietsma JH, Klis FM et al (2005) The structure of cell wall alpha-glucan from fission yeast. Glycobiology. 15(3):245-257. https://doi.org/10.1093/glycob/cwi002

Gu X, Bar-Peled M (2004) The biosynthesis of UDP-galacturonic acid in plants. Functional cloning and characterization of Arabidopsis UDP-D-glucuronic acid 4-epimerase. Plant Physiol. 136(4):4256-4264. https://doi.org/10.1104/ pp.104.052365

Hamann T, Bennett M, Mansfield J, Somerville C (2009) Identification of cell-wall stress as a hexose-dependent and osmosensitive regulator of plant responses. Plant J 57(6):1015-1026. https://doi.org/10.1111/j.1365-313X.2008. 03744.x

Harholt J, Suttangkakul A, Vibe SH (2010) Biosynthesis of pectin. Plant physiol. 153(2):384. https://doi.org/10.1104/pp.110.156588

Haruta M, Sabat G, Stecker K, Minkoff BB, Sussman MR (2014) A peptide hormone and its receptor protein kinase regulate plant cell expansion. Science. 343(6169):408-411. https://doi.org/10.1126/science.1244454

Hematy K, Sado PE, Van Tuinen A, Rochange S, Desnos T, Balzergue S et al (2007) A receptor-like kinase mediates the response of Arabidopsis cells to the inhibition of cellulose synthesis. Curr Biol. 17(11):922-931. https://doi.org/10.1 016/j.cub.2007.05.018

Hernandez-Blanco C, Feng DX, Hu J, Sanchez-Vallet A, Deslandes L, Llorente F et al (2007) Impairment of cellulose synthases required for Arabidopsis secondary cell wall formation enhances disease resistance. Plant Cell. 19(3): 890-903. https://doi.org/10.1105/tpc.106.048058

Hofte H, Voxeur A (2017) Plant cell walls. Curr Biol. 27(17):R865-RR70. https://doi. org/10.1016/j.cub.2017.05.025

Huang J, Gu M, Lai Z, Fan B, Shi K, Zhou YH et al (2010) Functional analysis of the Arabidopsis PAL gene family in plant growth, development, and response to environmental stress. Plant Physiol. 153(4):1526-1538. https://doi.org/10.1104/ pp.110.157370

Huckelhoven R (2007) Cell wall-associated mechanisms of disease resistance and susceptibility. Annu Rev Phytopathol. 45:101-127. https://doi.org/10.1146/a nnurev.phyto.45.062806.094325

Jin C (2012) Protein glycosylation in Aspergillus fumigatus is essential for cell wall synthesis and serves as a promising model of multicellular eukaryotic development. Int J Microbiol. 2012:654251. https://doi.org/10.1155/2012/654251

Johnson JM, Thurich J, Petutschnig EK, Altschmied L, Meichsner D, Sherameti I et al (2018) A poly(A) ribonuclease controls the cellotriose-based interaction between Piriformospora indica and its host Arabidopsis. Plant Physiol. 176(3): 2496-2514. https://doi.org/10.1104/pp.17.01423

Jones JD, Dangl JL (2006) The plant immune system. Nature. 444(7117):323-329. https://doi.org/10.1038/nature05286

Klis FM, de Groot P, Hellingwerf K (2001) Molecular organization of the cell wall of Candida albicans. Med mycol. 39(Suppl 1):1-8

Kohorn BD, Johansen S, Shishido A, Todorova T, Martinez R, Defeo E et al (2009) Pectin activation of MAP kinase and gene expression is WAK2 dependent. Plant J. 60(6):974-982. https://doi.org/10.1111/j.1365-313X.2009.04016.x

Kohorn BD, Kohorn SL (2012) The cell wall-associated kinases, WAKs, as pectin receptors. Front Plant Sci. 3:88. https://doi.org/10.3389/fpls.2012.00088

Kubicek CP, Starr TL, Glass NL (2014) Plant cell wall-degrading enzymes and their secretion in plant-pathogenic fungi. Annu Rev Phytopathol. 52:427-451. https://doi.org/10.1146/annurev-phyto-102313-045831

Lee C, Teng Q, Zhong R, Ye ZH (2011) The four Arabidopsis reduced wall acetylation genes are expressed in secondary wall-containing cells and required for the acetylation of xylan. Plant Cell Physiol. 52(8):1289-1301. https://doi.org/10.1093/pcp/pcr075

Lev S, Horwitz BA (2003) A mitogen-activated protein kinase pathway modulates the expression of two cellulase genes in Cochliobolus heterostrophus during plant infection. Plant Cell. 15(4):835-844. https://doi.org/10.1105/tpc.010546

Li H, Zhou SY, Zhao WS, Su SC, Peng YL (2009) A novel wall-associated receptor-like protein kinase gene, OsWAK1, plays important roles in rice blast disease resistance. Plant Mol Biol. 69(3):337-346. https://doi.org/10.1007/s11103-008-9430-5

Li Q, Fu J, Qin X, Yang W, Qi J, Li Z et al (2020a) Systematic analysis and functional validation of citrus pectin acetylesterases (CSPAEs) reveals that CSPAE2 negatively regulates citrus bacterial canker development. Int J Mol Sci 21(24). https://doi.org/10.3390/ijms21249429 
Li W, Wang K, Chern M, Liu Y, Zhu Z, Liu J et al (2020b) Sclerenchyma cell thickening through enhanced lignification induced by OsMYB30 prevents fungal penetration of rice leaves. New Phytol. 226(6):1850-1863. https://doi. org/10.1111/nph.16505

Lin W, Tang W, Anderson CT, Yang Z (2018) FERONIA's sensing of cell wall pectin activates ROP GTPase signaling in Arabidopsis. bioRxiv:269647. https://doi. org/10.1101/269647

Lionetti V, Cervone F, Bellincampi D (2012) Methyl esterification of pectin plays a role during plant-pathogen interactions and affects plant resistance to diseases. J Plant Physiol. 169(16):1623-1630. https://doi.org/10.1016/j.jplph.2 012.05 .006

Lionetti V, Raiola A, Camardella L, Giovane A, Obel N, Pauly M et al (2007) Overexpression of pectin methylesterase inhibitors in Arabidopsis restricts fungal infection by Botrytis cinerea. Plant Physiol. 143(4):1871-1880. https:// doi.org/10.1104/pp.106.090803

Lionetti V, Raiola A, Cervone F, Bellincampi D (2014) Transgenic expression of pectin methylesterase inhibitors limits tobamovirus spread in tobacco and Arabidopsis. Mol Plant Pathol. 15(3):265-274. https://doi.org/10.1111/mpp.12090

Liu N, Sun Y, Pei Y, Zhang X, Wang P, Li X et al (2018) A pectin methylesterase inhibitor enhances resistance to Verticillium Wilt. Plant Physiol. 176(3):22022220. https://doi.org/10.1104/pp.17.01399

Liu S, Wang J, Han Z, Gong X, Zhang H, Chai J (2016) Molecular mechanism for fungal cell wall recognition by rice chitin receptor OsCEBiP. Structure. 24(7): 1192-1200. https://doi.org/10.1016/j.str.2016.04.014

Liu T, Liu Z, Song C, Hu Y, Han Z, She J et al (2012) Chitin-induced dimerization activates a plant immune receptor. Science. 336(6085):1160-1164. https://doi. org/10.1126/science.1218867

Locci F, Benedetti M, Pontiggia D, Citterico M, Caprari C, Mattei B et al (2019) An Arabidopsis berberine bridge enzyme-like protein specifically oxidizes cellulose oligomers and plays a role in immunity. Plant J. 98(3):540-554 https://doi.org/10.1111/tpj.14237

Lombard V, Bernard T, Rancurel C, Brumer H, Coutinho PM, Henrissat B (2010) A hierarchical classification of polysaccharide lyases for glycogenomics. Biochem J. 432(3):437-444. https://doi.org/10.1042/BJ20101185

Lopez-Cruz J, Finiti I, Fernandez-Crespo E, Crespo-Salvador O, Garcia-Agustin P, Gonzalez-Bosch C (2014) Absence of endo-1,4- $\beta$-glucanase KOR1 alters the jasmonate-dependent defence response to Pseudomonas syringae in Arabidopsis. J Plant Physiol. 171(16):1524-1532. https://doi.org/10.1016/j. jplph.2014.07.006

Luna E, Pastor V, Robert J, Flors V, Mauch-Mani B, Ton J (2010) Callose deposition: a multifaceted plant defense response. Mol Plant Microbe Interact. 24(2):183193. https://doi.org/10.1094/MPMI-07-10-0149

Ma Z, Song T, Zhu L, Ye W, Wang Y, Shao Y et al (2015) A phytophthora sojae glycoside hydrolase 12 protein is a major virulence factor during soybean infection and is recognized as a PAMP. Plant Cell. 27(7):2057-2072. https:// doi.org/10.1105/tpc. 15.00390

Ma Z, Zhu L, Song T, Wang Y, Zhang Q, Xia Y et al (2017) A paralogous decoy protects Phytophthora sojae apoplastic effector PsXEG1 from a host inhibitor. Science. 355(6326):710-714. https://doi.org/10.1126/science.aai7919

Manabe Y, Nafisi M, Verhertbruggen Y, Orfila C, Gille S, Rautengarten C et al (2011) Loss-of-function mutation of REDUCED WALL ACETYLATION2 in Arabidopsis leads to reduced cell wall acetylation and increased resistance to Botrytis cinerea. Plant Physiol. 155(3):1068-1078. https://doi.org/10.1104/pp.110.168989

Manabe Y, Verhertbruggen Y, Gille S, Harholt J, Chong SL, Pawar PM et al (2013) Reduced wall acetylation proteins play vital and distinct roles in cell wall $\mathrm{O}$ acetylation in Arabidopsis. Plant Physiol. 163(3):1107-1117. https://doi.org/1 0.1104/pp.113.225193

Mang H, Feng B, Hu Z, Boisson-Dernier A, Franck CM, Meng X et al (2017) Differential regulation of two-tiered plant immunity and sexual reproduction by ANXUR receptor-like kinases. Plant Cell. 29(12):3140-3156. https://doi. org/10.1105/tpc.17.00464

Mary Wanjiru W, Zhensheng K, Buchenauer H (2002) Importance of cell wall degrading enzymes produced by Fusarium graminearum during infection of wheat heads. Eur J Plant Pathol. 108(8):803-810. https://doi.org/10.1023/A:1 020847216155

Masachis S, Segorbe D, Turrà D, Leon-Ruiz M, Fürst U, El Ghalid M et al (2016) A fungal pathogen secretes plant alkalinizing peptides to increase infection. Nat Microbiol 1(6). https://doi.org/10.1038/nmicrobiol.2016.43

McMillan GP, Hedley D, Fyffe L, Pérombelon MCM (1993) Potato resistance to soft-rot erwinias is related to cell wall pectin esterification. Physiol Mol Plant P. 42(4):279-289. https://doi.org/10.1006/pmpp.1993.1026
Melida H, Bacete L, Ruprecht C, Rebaque D, Del Hierro I, Lopez G et al (2020) Arabinoxylan-oligosaccharides act as damage associated molecular patterns in plants regulating disease resistance. Front Plant Sci. 11:1210. https://doi. org/10.3389/fpls.2020.01210

Mélida H, Largo-Gosens A, Novo-Uzal E, Santiago R, Pomar F, García P et al (2015) Ectopic lignification in primary cellulose-deficient cell walls of maize cell suspension cultures. J Integr Plant Biol. 57(4):357-372. https://doi.org/1 $0.1111 / j \mathrm{jpb} .12346$

Melida H, Sopena-Torres S, Bacete L, Garrido-Arandia M, Jorda L, Lopez G et al (2018) Nonbranched $\beta-1,3-$ glucan oligosaccharides trigger immune responses in Arabidopsis. Plant J. 93(1):34-49. https://doi.org/10.1111/tpj.13755

Mertz RA, Olek AT, Carpita NC (2012) Alterations in cell-wall glycosyl linkage structure of Arabidopsis murus mutants. Carbohydrate Polymers. 89(2):331339. https://doi.org/10.1016/j.carbpol.2012.02.044

Miedes E, Vanholme R, Boerjan W, Molina A (2014) The role of the secondary cell wall in plant resistance to pathogens. Front Plant Sci. 5:358. https://doi.org/1 $0.3389 /$ fpls.2014.00358

Nicaise V, Roux M, Zipfel C (2009) Recent advances in PAMP-triggered immunity against bacteria: pattern recognition receptors watch over and raise the alarm. Plant Physiol. 150(4):1638-1647. https://doi.org/10.1104/pp.109.139709

Niture SK, Kumar AR, Pant A (2006) Role of glucose in production and repression of polygalacturonase and pectate lyase from phytopathogenic fungus Fusarium moniliforme NCIM 1276. World J Microb and Biot. 22(9):893-899. https://doi.org/10.1007/s11274-006-9119-3

O'Neill M, Albersheim P (1990) Darvill A. 12 - The pectic polysaccharides of primary cell walls. In: Dey PM (ed) Methods in Plant Biochemistry. Academic Press, pp 415-441

Osorio S, Castillejo C, Quesada MA, Medina-Escobar N, Brownsey GJ, Suau R et al (2008) Partial demethylation of oligogalacturonides by pectin methyl esterase 1 is required for eliciting defence responses in wild strawberry (Fragaria vesca). Plant J. 54(1):43-55. https://doi.org/10.1111/j.1365-313X.2007. 03398.x

Panstruga R, Parker JE, Schulze-Lefert P (2009) SnapShot: Plant immune response pathways. Cell 136(5):978 e1-978 e3. https://doi.org/10.1016/..cell.2009.02.020

Park YB, Cosgrove DJ (2015) Xyloglucan and its interactions with other components of the growing cell wall. Plant Cell Physiol. 56(2):180-194. https://doi.org/10.1093/pcp/pcu204

Pauly M, Qin Q, Greene H, Albersheim P, Darvill A, York WS (2001) Changes in the structure of xyloglucan during cell elongation. Planta. 212(5):842-850. https:// doi.org/10.1007/s004250000448

Pauly M, Scheller HV (2000) O-Acetylation of plant cell wall polysaccharides: identification and partial characterization of a rhamnogalacturonan O-acetyltransferase from potato suspension-cultured cells. Planta. 210(4):659-667. https://doi.org/10.1007/s004250050057

Persson S, Paredez A, Carroll A, Palsdottir H, Doblin M, Poindexter P et al (2007) Genetic evidence for three unique components in primary cell-wall cellulose synthase complexes in Arabidopsis. Proc Natl Acad Sci USA. 104(39):15566. https://doi.org/10.1073/pnas.0706592104

Philippe F, Pelloux J, Rayon C (2017) Plant pectin acetylesterase structure and function: new insights from bioinformatic analysis. BMC Genomics. 18(1):456. https://doi.org/10.1186/s12864-017-3833-0

Pogorelko G, Lionetti V, Fursova O, Sundaram RM, Qi M, Whitham SA et al (2013) Arabidopsis and Brachypodium distachyon transgenic plants expressing Aspergillus nidulans acetylesterases have decreased degree of polysaccharide acetylation and increased resistance to pathogens. Plant Physiol. 162(1):9-23. https://doi.org/10.1104/pp.113.214460

Qu S, Zhang X, Song Y, Lin J, Shan X (2017) THESEUS1 positively modulates plant defense responses against Botrytis cinerea through GUANINE EXCHANGE FACTOR4 signaling. J Integr Plant Biol. 59(11):797-804. https://doi.org/1 $0.1111 /$ jipb. 12565

Raes J, Rohde A, Christensen JH, Van de Peer Y, Boerjan W (2003) Genome-wide characterization of the lignification toolbox in Arabidopsis. Plant Physiol. 133(3):1051-1071. https://doi.org/10.1104/pp.103.026484

Raiola A, Lionetti V, Elmaghraby I, Immerzeel P, Mellerowicz EJ, Salvi G et al (2010) Pectin methylesterase is induced in Arabidopsis upon infection and is necessary for a successful colonization by necrotrophic pathogens. Mol Plant Microbe Interact. 24(4):432-440. https://doi.org/10.1094/MPMI-07-10-0157

Ramirez V, Agorio A, Coego A, Garcia-Andrade J, Hernandez MJ, Balaguer B et al (2011) MYB46 modulates disease susceptibility to Botrytis cinerea in Arabidopsis. Plant Physiol. 155(4):1920-1935. https://doi.org/10.1104/pp.110.1 71843 
Randoux B, Renard-Merlier D, Mulard G, Rossard S, Duyme F, Sanssené J et al (2010) Distinct defenses induced in wheat against powdery mildew by acetylated and nonacetylated oligogalacturonides. Phytopathology. 100(12): 1352-1363. https://doi.org/10.1094/PHYTO-03-10-0086

Rebaque D, Del Hierro I, Lopez G, Bacete L, Vilaplana F, Dallabernardina P et al (2021) Cell wall-derived mixed-linked $\beta$-1,3/1,4-glucans trigger immune responses and disease resistance in plants. Plant J. https://doi.org/10.1111/ tpj.15185

Ridley BL, O'Neill MA, Mohnen D (2001) Pectins: structure, biosynthesis, and oligogalacturonide-related signaling. Phytochemistry. 57(6):929-967. https:// doi.org/10.1016/S0031-9422(01)00113-3

Robert S, Mouille G, Höfte H (2004) The mechanism and regulation of cellulose synthesis in primary walls: lessons from cellulose-deficient Arabidopsis mutants. Cellulose. 11(3):351-364. https://doi.org/10.1023/B:CELL.000004641 5.45774 .80

Rogers LA, Dubos C, Surman C, Willment J, Cullis IF, Mansfield SD et al (2005) Comparison of lignin deposition in three ectopic lignification mutants. New Phytol. 168(1):123-140. https://doi.org/10.1111/j.1469-8137.2005.01496.x

Rohde A, Morreel K, Ralph J, Goeminne G, Hostyn V, De Rycke R et al (2004) Molecular phenotyping of the pal1 and pal2 mutants of Arabidopsis thaliana reveals far-reaching consequences on phenylpropanoid, amino acid, and carbohydrate metabolism. Plant Cell. 16(10):2749-2771. https://doi.org/10.11 05/tpc.104.023705

Rovenich H, Zuccaro A, Thomma BP (2016) Convergent evolution of filamentous microbes towards evasion of glycan-triggered immunity. New Phytol. 212(4): 896-901. https://doi.org/10.1111/nph.14064

Salvador P, Lasserre T (2010) Inventors; ELICITYL, assignee. Process for increasing plants resistance to an abiotic stress. 2010/08/03/Application date.

Sampedro J, Pardo B, Gianzo C, Guitian E, Revilla G, Zarra I (2010) Lack of axylosidase activity in Arabidopsis alters xyloglucan composition and results in growth defects. Plant Physiol. 154(3):1105-1115. https://doi.org/10.1104/pp.11 0.163212

Savatin DV, Bisceglia NG, Marti L, Fabbri C, Cervone F, De Lorenzo G (2014) The Arabidopsis NUCLEUS- AND PHRAGMOPLAST-LOCALIZED KINASE1-related protein kinases are required for elicitor-induced oxidative burst and immunity. Plant Physiol. 165(3):1188-1202. https://doi.org/10.1104/pp.114.23 6901

Scheller HV, Ulvskov P (2010) Hemicelluloses. Annu Rev Plant Biol. 61:263-289. https://doi.org/10.1146/annurev-arplant-042809-112315

Schultink A, Liu L, Zhu L, Pauly M (2014) Structural diversity and function of xyloglucan sidechain substituents. Plants (Basel). 3(4):526-542. https://doi. org/10.3390/plants3040526

Schulze B, Mentzel T, Jehle AK, Mueller K, Beeler S, Boller T et al (2010) Rapid heteromerization and phosphorylation of ligand-activated plant transmembrane receptors and their associated kinase BAK1. J Biol Chem. 285(13):9444-9451. https://doi.org/10.1074/jbc.M109.096842

Shaku M, Ealand C, Matlhabe O, Lala R, Kana BD (2020) Peptidoglycan biosynthesis and remodeling revisited. Adv Appl Microbiol. 112:67-103. https://doi.org/10.1016/bs.aambs.2020.04.001

Shimizu T, Nakano T, Takamizawa D, Desaki Y, Ishii-Minami N, Nishizawa Y et al (2010) Two LysM receptor molecules, CEBiP and OsCERK1, cooperatively regulate chitin elicitor signaling in rice. Plant J. 64(2):204-214. https://doi. org/10.1111/j.1365-313X.2010.04324.X

Sieber P, Schorderet M, Ryser U, Buchala A, Kolattukudy P, Métraux JP et al (2000) Transgenic Arabidopsis plants expressing a fungal cutinase show alterations in the structure and properties of the cuticle and postgenital organ fusions. Plant Cell. 12(5):721-738. https://doi.org/10.1105/tpc.12.5.721

Silva-Sanzana C, Celiz-Balboa J, Garzo E, Marcus SE, Parra-Rojas JP, Rojas B et al (2019) Pectin methylesterases modulate plant homogalacturonan status in defenses against the Aphid Myzus persicae. Plant Cell. 31(8):1913-1929. https://doi.org/10.1105/tpc.19.00136

Simpson SD, Ashford DA, Harvey DJ, Bowles DJ (1998) Short chain oligogalacturonides induce ethylene production and expression of the gene encoding aminocyclopropane 1-carboxylic acid oxidase in tomato plants. Glycobiology. 8(6):579-583. https://doi.org/10.1093/glycob/8.6.579

Smith CA (2006) Structure, Structure, function and dynamics in the mur family of bacterial cell wall ligases. J Mol Biol. 362(4):640-655. https://doi.org/10.1016/j. jmb.2006.07.066

Somerville C (2006) Cellulose synthesis in higher plants. Annu Rev Cell Dev Biol. 22:53-78. https://doi.org/10.1146/annurev.cellbio.22.022206.160206
Souza CA, Li S, Lin AZ, Boutrot F, Grossmann G, Zipfel C et al (2017) Cellulosederived oligomers act as damage-associated molecular patterns and trigger defense-like responses. Plant Physiol. 173(4):2383-2398. https://doi.org/10.11 04/pp.16.01680

Stegmann M, Monaghan J, Smakowska-Luzan E, Rovenich H, Lehner A, Holton N et al (2017) The receptor kinase FER is a RALF-regulated scaffold controlling plant immune signaling. Science. 355(6322):287-289. https://doi.org/10.1126/ science.aal2541

Sterling JD, Quigley HF, Orellana A, Mohnen D (2001) The catalytic site of the pectin biosynthetic enzyme a-1,4-galacturonosyltransferase is located in the Jumen of the Golgi. Plant Physiol. 127(1):360. https://doi.org/10.1104/pp.12 7.1.360

Stranne M, Ren Y, Fimognari L, Birdseye D, Yan J, Bardor M et al (2018) TBL10 is required for $\mathrm{O}$-acetylation of pectic rhamnogalacturonan-I in Arabidopsis thaliana. Plant J. 96(4):772-785. https://doi.org/10.1111/tpj.14067

Sun A, Yu B, Zhang Q, Peng Y, Yang J, Sun Y et al (2020) MYC2-activated TRIC HOME BIREFRINGENCE-LIKE37 acetylates cell walls and enhances herbivore resistance. Plant Physiol. 184(2):1083-1096. https://doi.org/10.1104/pp.20. 00683

Taylor NG (2008) Cellulose biosynthesis and deposition in higher plants. New Phytol. 178(2):239-252. https://doi.org/10.1111/j.1469-8137.2008.02385.x

Taylor NG, Gardiner JC, Whiteman R, Turner SR (2004) Cellulose synthesis in the Arabidopsis secondary cell wall. Cellulose. 11(3):329-338. https://doi.org/10.1 023/B:CELL.0000046405.11326.a8

Trusov Y, Rookes JE, Chakravorty D, Armour D, Schenk PM, Botella JR (2006) Heterotrimeric $\mathrm{G}$ proteins facilitate Arabidopsis resistance to necrotrophic pathogens and are involved in jasmonate signaling. Plant Physiol. 140(1): 210-220. https://doi.org/10.1104/pp.105.069625

Underwood W (2012) The plant cell wall: a dynamic barrier against pathogen invasion. Front Plant Sci. 3:85. https://doi.org/10.3389/fpls.2012.00085

Urbanowicz BR, Pena MJ, Moniz HA, Moremen KW, York WS (2014) Two Arabidopsis proteins synthesize acetylated xylan in vitro. Plant J. 80(2):197206. https://doi.org/10.1111/tpj.12643

Vaahtera L, Schulz J, Hamann T (2019) Cell wall integrity maintenance during plant development and interaction with the environment. Nat Plants. 5(9): 924-932. https://doi.org/10.1038/s41477-019-0502-0

van den Brink J, de Vries RP (2011) Fungal enzyme sets for plant polysaccharide degradation. Appl Microbiol Biotechnol. 91(6):1477-1492. https://doi.org/10.1 007/s00253-011-3473-2

Van der Does D, Boutrot F, Engelsdorf T, Rhodes J, McKenna JF, Vernhettes S et al (2017) The Arabidopsis leucine-rich repeat receptor kinase MIK2/LRR-KISS connects cell wall integrity sensing, root growth and response to abiotic and biotic stresses. PLoS Genet. 13(6):e1006832. https://doi.org/10.1371/journal. pgen.1006832

Vogel JP, Raab TK, Schiff C, Somerville SC (2002) PMR6, a pectate lyase-like gene required for powdery mildew susceptibility in Arabidopsis. Plant Cell. 14(9): 2095-2106. https://doi.org/10.1105/tpc.003509

Vogel JP, Raab TK, Somerville CR, Somerville SC (2004) Mutations in PMR5 result in powdery mildew resistance and altered cell wall composition. Plant J. 40(6):968-978. https://doi.org/10.1111/j.1365-313X.2004.02264.x

Vollmer W, Blanot D, de Pedro MA (2008) Peptidoglycan structure and architecture. FEMS Microbiol Rev. 32(2):149-167. https://doi.org/10.1111/j.1 574-6976.2007.00094.x

Volpi C, Janni M, Lionetti V, Bellincampi D, Favaron F, D'Ovidio R (2011) The ectopic expression of a pectin methyl esterase inhibitor increases pectin methyl esterification and limits fungal diseases in wheat. Mol Plant Microbe Interact. 24(9):1012-1019. https://doi.org/10.1094/MPMI-01-110021

Voxeur A, Habrylo O, Guenin S, Miart F, Soulie MC, Rihouey C et al (2019) Oligogalacturonide production upon Arabidopsis thaliana-Botrytis cinerea interaction. Proc Natl Acad Sci USA. 116(39):19743-19752. https://doi.org/10.1 073/pnas.1900317116

Wang X, Hou S, Wu Q, Lin M, Acharya BR, Wu D et al (2017) IDL6-HAE/HSL2 impacts pectin degradation and resistance to Pseudomonas syringae pv tomato DC3000 in Arabidopsis leaves. Plant J. 89(2):250-263. https://doi.org/1 $0.1111 /$ tpj.13380

Wang Y, Xu Y, Sun Y, Wang H, Qi J, Wan B et al (2018) Leucine-rich repeat receptor-like gene screen reveals that Nicotiana $R X E G 1$ regulates glycoside hydrolase 12 MAMP detection. Nat Commun. 9(1):594. https://doi.org/10.103 8/s41467-018-03010-8 
Wolf S, Hématy K, Höfte H (2012) G Growth control and cell wall signaling in plants. Annu Rev Plant Biol. 63(1):381-407. https://doi.org/10.1146/annurev-a rplant-042811-105449

Wolf S, Mouille G, Pelloux J (2009) Homogalacturonan methyl-esterification and plant development. Mol Plant. 2(5):851-860. https://doi.org/10.1093/mp/ ssp066

Xiao S, Hu Q, Shen J, Liu S, Yang Z, Chen K et al (2021) GhMYB4 downregulates lignin biosynthesis and enhances cotton resistance to Verticillium dahliae. Plant Cell Rep. 40(4):735-751. https://doi.org/10.1007/s00299-021-02672-x

Xiong G, Cheng K, Pauly M (2013) Xylan O-acetylation impacts xylem development and enzymatic recalcitrance as indicated by the Arabidopsis mutant tb/29. Mol Plant. 6(4):1373-1375. https://doi.org/10.1093/mp/sst014

Xu G, Zhong X, Shi Y, Liu Z, Jiang N, Liu J et al (2020) A fungal effector targets a heat shock-dynamin protein complex to modulate mitochondrial dynamics and reduce plant immunity. Sci Adv 6(48):eabb7719. https://doi.org/10.1126/ sciadv.abb7719

Yakoby N, Kobiler I, Dinoor A, Prusky D (2000) pH regulation of pectate lyase secretion modulates the attack of Colletotrichum gloeosporioides on avocado fruits. Appl Environ Microbiol. 66(3):1026-1030. https://doi.org/10.1128/aem. 66.3.1026-1030.2000

Yang C, Liu R, Pang J, Ren B, Zhou H, Wang G et al (2021) Poaceae-specific cell wall-derived oligosaccharides activate plant immunity via OsCERK1 during Magnaporthe oryzae infection in rice. Nature Commun 12(1). https://doi.org/1 $0.1038 / 541467-021-22456-x \backslash$

Yuan Y, Teng Q, Zhong R, Ye ZH (2013) The Arabidopsis DUF231 domaincontaining protein ESK1 mediates 2-O- and 3-O-acetylation of xylosyl residues in xylan. Plant Cell Physiol. 54(7):1 186-1199. https://doi.org/10.1093/ pcp/pct070

Zhang L, Kars I, Essenstam B, Liebrand TW, Wagemakers L, Elberse J et al (2014) Fungal endopolygalacturonases are recognized as microbe-associated molecular patterns by the arabidopsis receptor-like protein responsiveness to botrytis polygalacturonases1. Plant Physiol. 164(1):352-364. https://doi.org/1 0.1104/pp.113.230698

Zhao Q, Dixon RA (2014) Altering the cell wall and its impact on plant disease: from forage to bioenergy. Annu Rev Phytopathol. 52(1):69-91. https://doi. org/10.1146/annurev-phyto-082712-102237

Zhong R, Cui D, Ye ZH (2019) Secondary cell wall biosynthesis. New Phytol. 221(4):1703-1723. https://doi.org/10.1111/nph.15537

Zhou F, Emonet A, Denervaud Tendon V, Marhavy P, Wu D, Lahaye T et al (2020) Co-incidence of damage and microbial patterns controls localized immune responses in roots. Cell. 180(3):440-453 e18. https://doi.org/10.1016/j.cell.202 0.01 .013

Zhou X, Liao H, Chern M, Yin J, Chen Y, Wang J et al (2018) Loss of function of a rice TPR-domain RNA-binding protein confers broad-spectrum disease resistance. Proc Natl Acad Sci USA. 115(12):3174. https://doi.org/10.1073/pna s. 1705927115

\section{Publisher's Note}

Springer Nature remains neutral with regard to jurisdictional claims in published maps and institutional affiliations. 